WSRC-MS-2000-00537R1

Identification of Thiothrix unzii in Two Distinct Ecosystems

2

\title{
LIST OF KEY WORDS
}

9 Thiothrix spp., groundwater, phylogenetic analysis, biofilm.

*Corresponding Author

13 Environmental Biotechnology Section

14 Savannah River Technology Center

15 Westinghouse Savannah River Company

16 Bldg. 704-8T (TNX)

Aiken, SC 29808

18

Phone (803)-557-7719

19

Fax (803)-557-7223

20

EMAIL r03.brigmon@srs.gov 
This document was prepared in conjunction with work accomplished under Contract No.

DE-AC09-96SR18500 with the U.S. Department of Energy.

\section{DISCLAIMER}

This report was prepared as an account of work sponsored by an agency of the United States Government. Neither the United States Government nor any agency thereof, nor any of their employees, makes any warranty, express or implied, or assumes any legal liability or responsibility for the accuracy, completeness, or usefulness of any information, apparatus, product or process disclosed, or represents that its use would not infringe privately owned rights. Reference herein to any specific commercial product, process or service by trade name, trademark, manufacturer, or otherwise does not necessarily constitute or imply its endorsement, recommendation, or favoring by the United States Government or any agency

thereof. The views and opinions of authors expressed herein do not necessarily state or reflect those of the United States Government or any agency thereof.

This report has been reproduced directly from the best available copy.

Available for sale to the public, in paper, from: U.S. Department of Commerce, National Technical Information Service, 5285 Port Royal Road, Springfield, VA 22161, phone: (800)

553-6847, fax: (703) 605-6900, email: orders@ntis.fedworld.gov online ordering: http://www.ntis.gov/ordering.htm

Available electronically at http://www.doe.gov/bridge

Available for a processing fee to U.S. Department of Energy and its contractors, in paper, from: U.S. Department of Energy, Office of Scientific and Technical Information, P.O. Box 62, Oak Ridge, TN 37831-0062, phone: (865 ) 576-8401, fax: (865) 576-5728, email: reports@ adonis.osti.gov 
WSRC-MS-2000-00537R1

1

2

3

4

5

6

7

8

9

10

Abstract

Molecular procedures were used to identify Thiothrix spp. in biofilms from sulfide-rich waters in two distinct Florida ecosystems. These Thiothrix spp.containing biofilms at these sites have been consistently observed for over 10 years. Clonal libraries of biofilm 16S rDNA from each site contained rDNA sequences that were 99 to $99.5 \%$ similar to Thiothrix unzii. 


\section{Summary}

The genus Thiothrix was created for ensheathed sulfur-oxidizing filamentous bacteria that deposit sulfur granules internally, attach to substrates, produce gliding gonidia, and form rosettes (Brigmon \& DeRidder, 1998). Thiothrix spp. have been described as a component of biofilms on a variety of surfaces in sulfide-containing flowing water in natural systems (Brigmon et al., 1995) and wastewater treatment plants (Williams \& Unz, 1989). The occurrence of Thiothrix as an ectosymbiont has been demonstrated for fresh water (Larkin et al., 1990) and salt-water (Polz et al., 1994) organisms. However, little is known about the molecular ecology of this genus. In flowing water with sulfide concentrations of at least $0.1 \mathrm{ppm}$, oxygen concentrations of less than $10 \%$ saturation and neutral pH, Thiothrix spp. attach to solid surfaces with holdfasts (Brigmon et al., 1995). In the springs and underwater limestone caves within the Floridan aquifer, visible white filamentous biofilms containing Thiothrix spp. have been observed as thin white mats or tufts with scattered distribution patterns on surfaces of rocks, sediments, and cave floors or filamentous masses in the water column (Brigmon et al., 1995).

In this study Thiothrix species were identified at two surficial sites with molecular techniques. We previously observed these biofilms to have similar physical appearances, physiological characteristics and sulfurous water sources. While there has been some anthropogenic influence on these aquatic systems, if left without treatment (i.e. chlorination), the same biofilm formation occurs 
(Brigmon et al, 1997). This is the first reported identification of Thiothrix unzii in a natural aquatic system.

\section{Materials and Methods}

Sampling Sites.

Biofilm samples were obtained from two groundwater-fed systems in municipal water tank at Palatka, Florida. At both of these sites, visible colonies of white filamentous biofilms containing Thiothrix spp. have been documented for over 10 years (Brigmon et al. 1997).

14 forceps and immediately placed in sterile 50-ml centrifuge tubes. The Orange 15 Springs samples were collected from the white filamentous biofilm covering the 16 surface of rocks in the spring run at a depth of $0.5 \mathrm{~m}$. The Palatka sample was 17 collected from a biofilm-covered aerator pan. The water chemistry at both 18 sampling sites was tested in the field for dissolved oxygen, $\mathrm{pH}$, and hydrogen 19 sulfide as previously described (Brigmon et al., 1997). Caution was used so that 20 the tubes were opened under the water, biofilm mats immediately placed into the 21 tubes, and capped before bringing to the surface. The tubes were stored in a cooler with ice and returned to the laboratory for processing. sampling by their typical white, rough, filamentous appearance (Larkin et al., 
1990). Initial microscopic examination of Thiothrix spp. distinguishing morphological characteristics including rosettes, filaments, gonidia, and sulfur granules was used for further presumptive identification (Williams and Unz, 1989). Confirmation of Thiothrix spp. in biofilm samples was made by monoclonal antibodies (MAb) specific for Thiothrix spp. with immunofluorescence as previously described (Brigmon et al., 1995).

\section{Sample Phylogenetic Analysis}

One milliliter of mat material was taken from each sample. This material was centrifuged at full speed in a microfuge for $5 \mathrm{~min}$, washed with sterile distilled water and resuspended in $0.5 \mathrm{ml}$ of sterile distilled water. The $16 \mathrm{~S}$ ribosomal DNA in each sample was PCR-amplified using Ready-To-Go PCR Beads (Pharmacia Biotech, Piscataway, NJ). The bacterial primer 27f, 5'-AGA GTT TGA TCM TGG CTC AG-3' (Lane, 1991) and the universal primer 1392r, 5'-ACG GGC GGT GTG TRC-3' (Lane, 1991) were used at a concentration of $0.8 \mu \mathrm{M}$. For each sample, $2 \mu \mathrm{g}$ of DNA, was added directly to a PCR reaction tube. The reaction mixtures were heated for $5 \mathrm{~min}$ at $94^{\circ} \mathrm{C}$, which lysed the cells. This lysate was used as a source of DNA without further purification. The denaturation, elongation, and annealing conditions were 1 min at $94{ }^{\circ} \mathrm{C}, 2$ minutes at $72{ }^{\circ} \mathrm{C}$ and $1 \mathrm{~min}$ at $61{ }^{\circ} \mathrm{C}$. The PCR products were purified by electrophoresis on a $0.8 \%$ agarose gel and eluted from the gel with a using Prep-A-Gene DNA Purification System (Biorad, Hercules). The amplified DNA was then ligated using T4 ligase into vector pCR 2.0 (Invitrogen, Carlsbad) using the vendor's protocol and transformed into E. coli Top 10 cells (Ausuvel et al., 1999, Miller et 
al., 1988). After ligation, approximately, 100 colonies containing PCR-amplified bacterial 16S rDNA inserts from each sample were found. PCR inserts were sequenced at the Molecular Genetics Instrumentation Facility at the University of Georgia. Primer 27f was used to sequence 3 bacterial clones from each sample. Approximately 700 base pairs from each clone were sequenced.

For FastA searches, approximately 500 nucleotides of the sequences were utilized to avoid ambiguous positions in some of the clones. Both GenBank and EMBL databases were searched. Sequence comparisons were performed with PHYLIP 3.5 (Felsenstein, 1993). Evolutionary distances were calculated using the Jukes-Cantor formula, and the Neighbor Joining algorithm was used to construct the phylogenetic trees. Bootstrap analysis was performed with 100 replicates.

\section{Results and Discussion}

The clonal library from each sample site contained one clone that was 99\%-99.5\% similar to Thiothrix unzii. These clones, TX1 and PL3, were 99.8\%

18 similar to each other, suggesting that they both represented the same or very

19 similar species. These two clones branched from the clade of Thiothrix spp. and 20 clustered most closely with Thiothrix unzii with bootstrap value of 100 (Figure 1

$21 \& 2$,data not shown) T. unzii has previously been found associated with wastewater systems (Howarth et al., 1999), and this is the first report of this taxon

23 in a natural spring. This result suggests that this group may be more widely 
distributed than previously known. The four other clones sequenced from the libraries were not related to the Thiothrix group and were less than $85 \%$ similar to each other. Presumably, they represent heterotrophic bacteria associated with these biofilms. The Thiothrix species was abundant enough in both mats to be detected in the Tx and PL clone libraries after sequencing only 3 clones. Moreover, this result is consistent with the previous observation that Thiothrix

Knowledge of the microbial ecology in these aquifers and associated spp. comprised $18 \% \mathrm{w} / \mathrm{w}$ of the biofilm in the Palatka municipal water storage tanks (Brigmon et al., 1997). Previous work at these two sites indicated morphological and immunological similarity of the biofilms at these two sites (Brigmon et al.,1995). The water chemistry of the groundwater analyzed in the field at sampling time were quite similar. For Orange Spring and Palatka the groundwater constituents were to determined to be respectively 1 and $1.5 \mathrm{ppm}$ sulfide, 2 and $5 \%$ dissolved oxygen, and 7.2 and $7.3 \mathrm{pH}$. These conditions are conducive to growth of Thiothrix spp. biofilms is limited. By increasing our understanding of the geomicrobial ecology of these environments, valuable information will be gained on our aquatic resources. This is important to document as anthropogenic pressure on these aquifers increases. Molecular procedures were applied here successfully to identify Thiothrix spp. in biofilms in two distinct ecosystems. These Thiothrix spp.-containing biofilms have been documented for over 10 years by microscopic, microbiological, and immunologic techniques. This confirmation by phylogenetic methods verifies the ecological distribution of related organisms in surficial 
WSRC-MS-2000-00537R1

systems supplied by geochemically similar groundwater (Brigmon et al., 1994,

1997). This is the first report of T. unzii in a natural system.

3

This paper was prepared in connection with work done under Contract No. DEAC09-96SR18500 with the U. S. Department of Energy. We thank the Oak

Ridge Institute for Science and Education (ORISE) for support of Ms. Furlong. 
WSRC-MS-2000-00537R1

\section{REFERENCES}

Ausuvel, F.M., R. Brent, R.E. Kingston, D.D. Moore, J. G. Seidman, J.A. Smith, and K. Struhl (eds.) 1999. Short Protocols in Molecular Biology. $4^{\text {th }}$ ed. JohnWiley and Sons, New York.

Benson D.A., Boguski M.S., Lipman D.J., Ostell J., Ouellette B.F., Rapp B.A., Wheeler D.L. (1999) Genbank. Nucleic Acids Research 27: 12-17.

Brigmon, R.L., G. Bitton, S.G. Zam, and B. O'Brien. (1995) Development and application of a monoclonal antibody against Thiothrix spp. Applied Environmental Microbiology. 61: 13-20.

Brigmon R. L. \& C. De Ridder. (1998) Symbiotic Relationship of Thiothrix spp. with Echinoderms. Applied Environmental Microbiology 64:3491-3495.

Brigmon, R.L., H.W. Martin, and H. Aldrich. 1997. Biofouling in aquatic systems by Thiothrix spp. Current Microbiology 35:169-174.

Felsenstein, J. (1993) PHYLIP: phylogeny inference package. University of Washington, Seattle.

Howarth, R., R. F. Unz, E. M. Seviour, R. J. Seviour, L. L. Blacjkall, R.W. Pickup, J.G. Jones, J. Yaguchi, and I. M. Head. (1999) Phylogenetic relationships 
between filamentous sulfur bacteria (Thiothrix spp. and Eikelboom type $021 \mathrm{~N}$ bacteria) isolated from wastewater-treatment plants and description of Thiothrix eikelboomi sp. Nov., Thiothrix unzii sp. Nov., Thiothrix fructosivorans sp. Nov. and Thiothrix defluvii sp. Nov. International Journal of Systematic Bacteriology 49, 1817-1827.

6

Larkin, J.M., M.C. Henk, and S.D. Burton. (1990) Occurrence of Thiothrix sp. attached to Mayfly larva and presence of a parasitic bacteria in the Thiothrix sp. Applied Environmental Microbiology 56, 357-361. of bacteria: Genetic Transformation of Campylobacter jejuni with Plasmid DNA. Proceedings of the National Academy of Sciences 85, 856-860. Cavanaugh. (1994) Phylogenetic analysis of a highly specific association between ectosymbiotic, sulfur-oxidizing bacteria and a marine nematode. Applied Environmental Microbiology 60, 4461-4467. 
Williams, T.M., and R.F. Unz. (1989) The nutrition of Thiothrix, type 021N, Beggiatoa, and Leucothrix strains. Water Research 2,15-22.

Figure 1. Phylogenetic tree generated by the neighbor-joining method from an alignment of 400 nucleotide positions showing the relationships between well PL and TX clones and described bacteria. PL and TX represent the samples from Palatka and Orange Springs, respectively. The scale bar indicates the Jukes Cantor distance. The number in parentheses indicates the accession number for the sequence. This tree was rooted using a Methanococcus maripaludis $16 \mathrm{~S}$ rDNA sequence. Bootstrap values greater than 50 are reported adjacent to each 11 node.

Figure 2. Phylogenetic tree generated by the neighbor-joining method from an

14 alignment of 659 nucleotide positions showing the relationships between the 15 Thiothrix clones and described bacteria in the Thiothrix group. PL and TX 16 represent the samples from Palatka and Orange Springs respectively. The scale 17 bar indicates the Jukes Cantor distance. The number in parentheses indicates the 18 accession number for the sequence. This tree was rooted using a Burkholderia 19 caryophylli $16 \mathrm{~S}$ rDNA sequence. Bootstrap values greater than 50 are reported 20 adjacent to each node. 


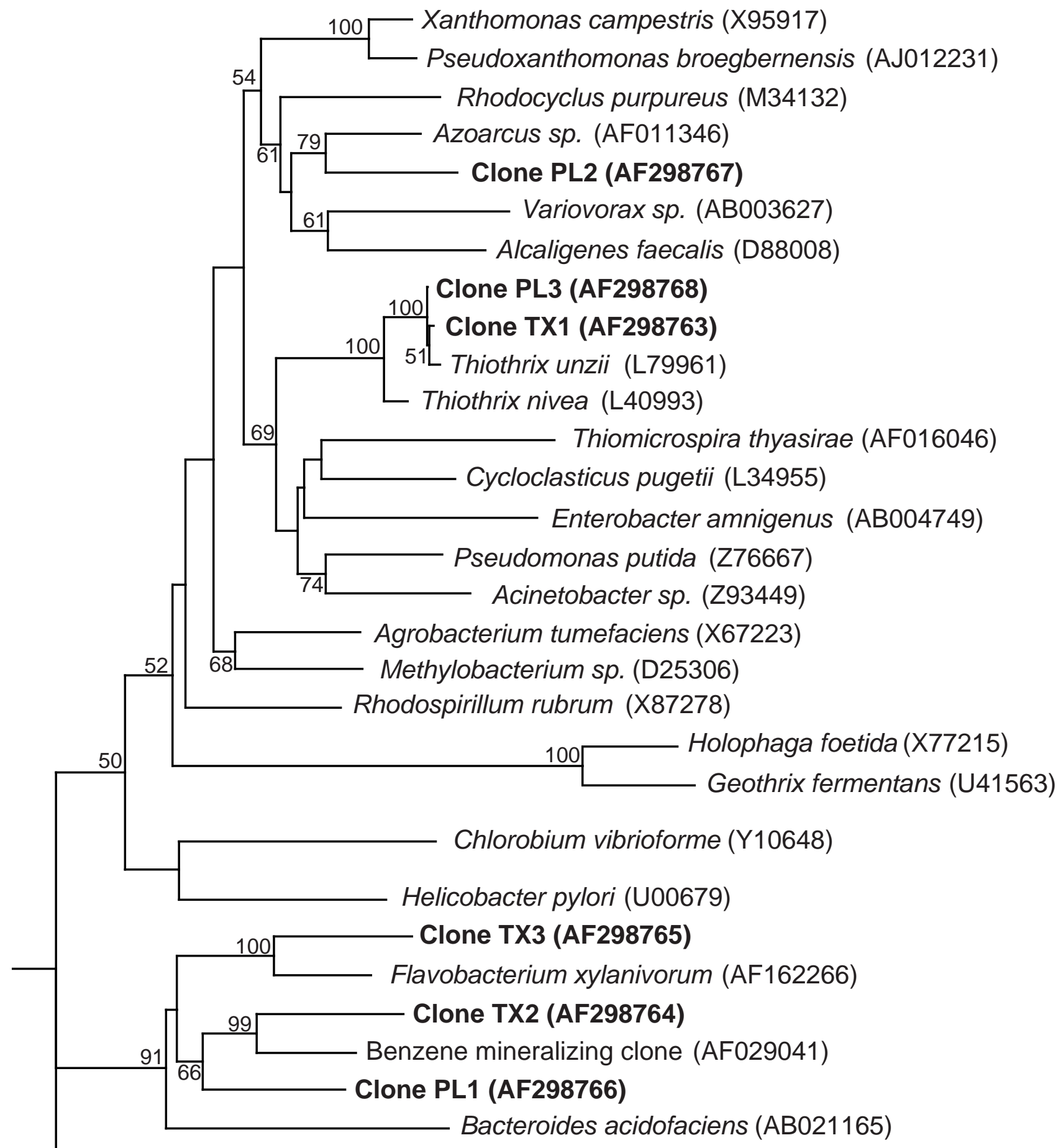

Methanococcus maripaludis (AF005049) 


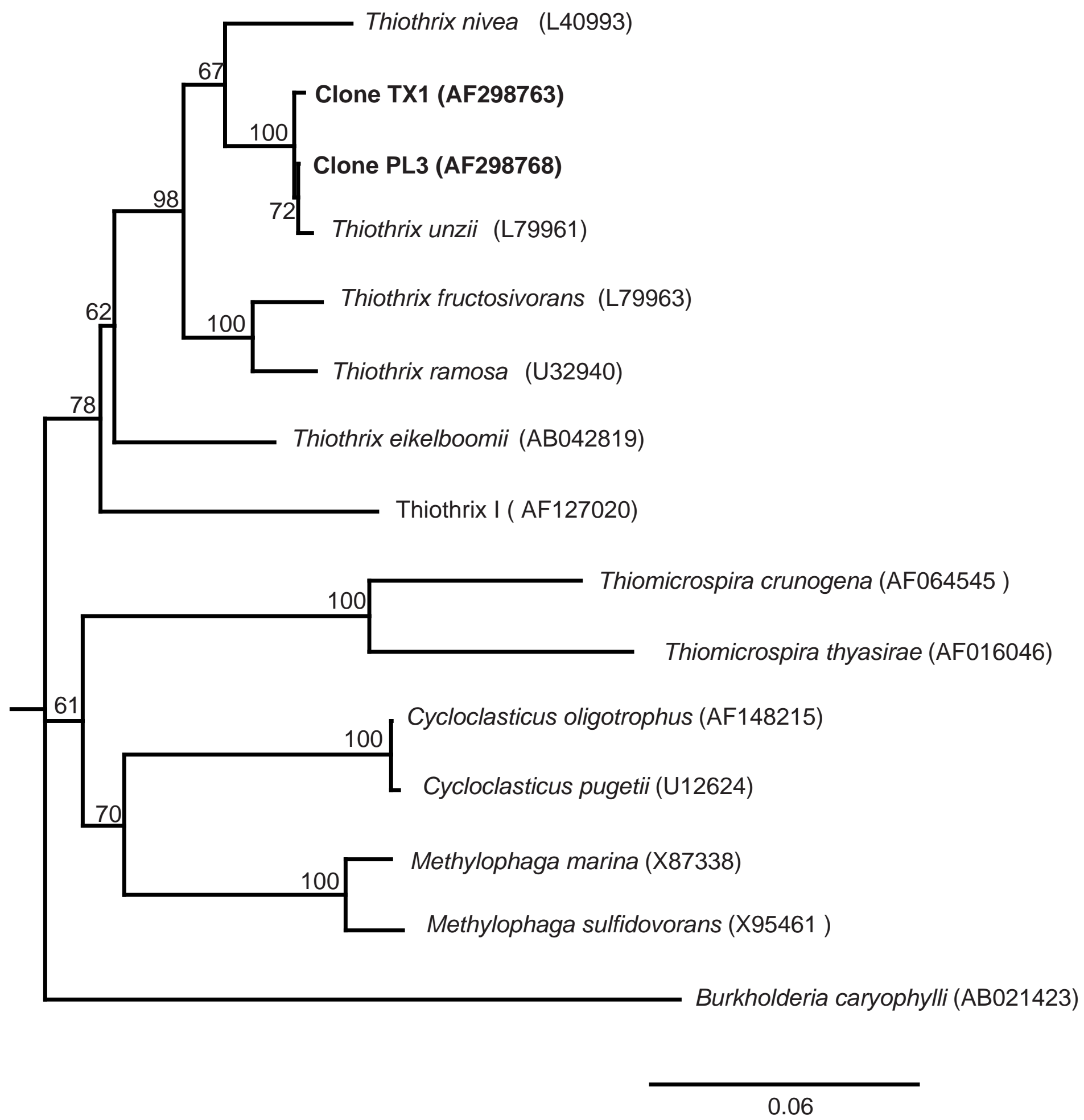

